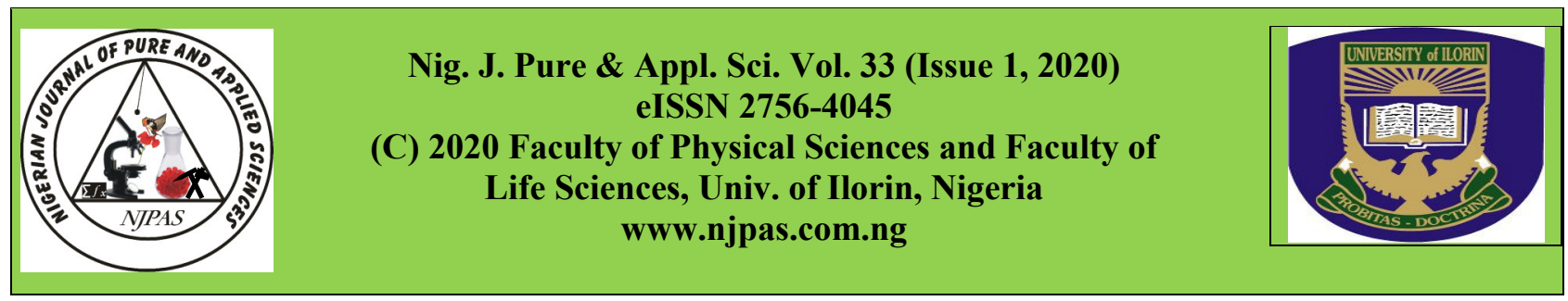

doi: http://dx.doi.org/10.48198/NJPAS/20.A07

\title{
Effects of Valproic Acid on Selected Kidney Function Indices in Rats
}

\author{
*A. Igunnu, O. O. Owolabi and I. O. Bankole
}

Department of Biochemistry, Faculty of Life Sciences, University of Ilorin, Ilorin, Nigeria.

\begin{abstract}
Valproic acid (VPA) has been demonstrated to exhibit anti-diabetic effect and attenuate hypertensive responses in animal models but its safety evaluation on the kidney has not been reported. This study investigated the effect of VPA on selected kidney function indices of rats. Twenty healthy Wistar rats were randomly grouped into 4 of 5 rats each. Rats in group 1 (control) were administered clean water only, while rats in groups 2, 3 and 4 were administered 100, 300 and $600 \mathrm{mg} / \mathrm{kg}$ body weight (bw) of VPA, respectively for 3 weeks. Serum concentrations of creatinine, urea, sodium, potassium, phosphate and chloride ions as well as the activities of alkaline phosphatase (ALP), acid phosphatase (ACP), aspartate aminotransferase (AST), and alanine aminotransferase (ALT) in the kidney and serum of rats were determined. VPA at the 3 doses administered did not significantly affect ( $p>0.05$ ) the kidney/body weight ratio, serum concentrations of creatinine, urea, sodium ion and phosphate ion when compared with control. VPA at $600 \mathrm{mg} / \mathrm{kg}$ bw alone and at both 300 and $600 \mathrm{mg} / \mathrm{kg}$ bw significantly increased $(p<0.05)$ the serum levels of potassium and chloride ions, respectively. VPA did not significantly affect $(\mathrm{p}>0.05)$ the kidney ALP and ALT activities as well as the serum ALP, ACP, AST and ALT activities but significantly increased $(\mathrm{p}<0.05)$ the kidney ACP and AST activities at $300 \mathrm{mg} / \mathrm{kg}$ bw. These results imply that treatment with VPA at higher doses may adversely affect the reabsorption of chloride ion in the kidney which may alter the acid/base balance and impair nerve impulse transmission.
\end{abstract}

Keywords: Valproic acid, diabetes, hypertension, kidney.

\section{Introduction}

Valproic acid (2-propylvaleric acid or 2propylpentanoic acid), a derivative of valeric acid, is a branched short-chain fatty acid forming a clear liquid at room temperature with half-life of 9 to 16 hours (Soori et al., 2015). Valproic acid (VPA) is quickly metabolized in the liver, and the various metabolites resulting from the metabolism are also pharmacologically active. Its bioavailability is ascribed to the high permeability of the cell membrane to this compound and the nearly absence of first pass hepatic mechanism (Lauterbach et al., 2010).

Valproic acid is generally used in clinics as an antiepileptic drug and for the treatment of bipolar disorders and migraine prophylaxis (Kostrouchova et al., 2007). It is extensively metabolized by microsomal glucuronide conjugation, mitochondrial beta-oxidation and cytochrome P450dependent omega (omega-1 and omega-2) oxidation (Perucca, 2002). The pharmacological effects of VPA involve increased gamma- 
aminobutyric acid (GABA)-ergic transmission, reduced release and/or effects of excitatory amino acids, blockade of voltage gated sodium channels and modulation of dopaminergic and serotoninergic transmission (Verrotti, 2010). VPA may

Page | 3688 regulate the expression of neuroprotective genes and protect against excitotoxicity (Bril et al., 2011).

Studies have indicated that targeting histone deacetylases (HDACs) is a promising therapeutic strategy for some diseases including diabetes mellitus (Biddinger and Kahn, 2006), hypertension (Alam et al., 2016) and cancers (Falkenberg and Johnstone, 2014). HDAC are enzymes that regulate the activities of histone acetyltransferases in chromatin remodeling and thereby play an essential role in gene transcription to regulate cell proliferation, migration and apoptosis, immune pathways and angiogenesis (Crosson et al., 2010).

Valproic acid (VPA), an HDAC inhibitor, has been demonstrated to exhibit anti-diabetic effect and attenuate hypertensive responses in animal models (Lee et al., 2013; Igunnu et al., 2019). VPA has also shown pharmacological characteristics similar to those of other anti-cancer agents, exerting effect on cell growth, differentiation and apoptosis (Lauterbach et al., 2010). However, its effect on a very vital organ, important for the body's homeostasis, the kidney, has not been reported. Therefore, this study evaluated the effect of VPA on selected kidney function indices of rats.

\section{Materials and Methods}

\section{Chemicals and Reagents}

Valproic acid was obtained from Sigma-Aldrich UK. Assay kits for the determination of alkaline phosphatase (ALP), acid phosphatase (ACP), aspartate aminotransferase (AST) and alanine aminotransferase (ALT) activities were obtained from Randox Laboratories Limited. The assay kits used for the determination of serum levels of electrolytes were obtained from Teco diagnostics. All other reagents used were of analytical grade and were prepared using distilled water.

\section{Experimental Animals}

Twenty (20) healthy female albino rats (Rattus norvegicus) with an average weight of $170-200 \mathrm{~g}$ used for this study were procured from the Animal House (Animal Breeding Unit) of the Department of Biochemistry, University of Ilorin, Ilorin, Nigeria. The rats were housed in well ventilated plastic cages under standard conditions and they were acclimatized for one week before treatment during which they were fed normal diet and water. The research was conducted in accordance with internationally accepted principle for laboratory animal use and care (Clarke et al., 1997; Garber et al., 2011).

\section{Animal Grouping and Drug Administration}

Twenty rats were randomly grouped into four (1 4) of five rats each. Each rat in the control group (group 1) was administered clean water orally for three weeks. Valproic acid was dissolved in clean water and doses of 100, 300 and $600 \mathrm{mg} / \mathrm{kg}$ body weight of valproic acid were administered orally to the rats in groups 2, 3 and 4 respectively for three weeks.

\section{Collection and Preparation of Samples}

At the end of the treatment period, the rats were slightly anaesthetized with diethyl ether, the neck area was quickly cleared of fur and skin to expose the jugular vein from which blood was collected into sample bottles. The blood samples were allowed to stand for $10 \mathrm{mins}$ at room temperature for clot formation and subsequently centrifuged at $3000 \mathrm{rpm}$ for $5 \mathrm{mins}$, after which the serum was pipetted out and stored in the freezer at $-20^{\circ} \mathrm{C}$ till needed for analysis.

Also, the rats were quickly dissected and the organ of interest (kidney) was isolated, cleaned of blood, weighed, suspended in an ice-cold $0.25 \mathrm{M}$ sucrose 
solution $(1: 5 \mathrm{w} / \mathrm{v})$ and homogenized. The homogenates were frozen overnight to allow complete cell lysis and maximum release of enzymes (Akanji et al., 1993).

\section{Page | 3689 Biochemical Assays}

Serum concentrations of urea and creatinine were determined using methods described by Amin et al. (2014). The serum levels of $\mathrm{Na}^{+}, \mathrm{K}^{+}, \mathrm{Cl}^{-}$and $\mathrm{PO}_{4}{ }^{2-}$ were determined using methods described in the Teco kit manuals. The activity of alkaline phosphatase was determined by the method of Wright et al. (1972). The activity of acid phosphatase was determined using the method described by Wright and Plumber (1974). The activities of alanine aminotransferase and aspartate aminotransferase were determined according to the method described by Reitman and Frankel (1957).

\section{Statistical Analysis}

Statistical analysis was carried out by one-way analysis of variance followed by post hoc Tukey's comparison test using statistical package for the social science (SPSS 16.0) statistical software. Results were expressed as means \pm standard error of mean (SEM) for five rats in each group. A value of $p<0.05$ was considered to be statistically significant.

\section{Results}

Valproic acid (VPA) at all the treatment doses (100, 300 and $600 \mathrm{mg} / \mathrm{kg} \mathrm{bw}$ ) administered did not significantly affect $(p>0.05)$ the kidney/body weight ratio of rats when compared with control (Table 1).

VPA at the 3 doses administered did not significantly affect $(p>0.05)$ serum concentrations of creatinine and urea when compared with control (Table 2). Also, treatment with VPA at the 3 doses studied did not significantly affect $(\mathrm{p}>0.05)$ serum concentrations of sodium and phosphate ions but VPA at $600 \mathrm{mg} / \mathrm{kg}$ bw alone and at both 300 and $600 \mathrm{mg} / \mathrm{kg}$ bw significantly increased $(\mathrm{p}<0.05)$ the serum levels of potassium and chloride ions, respectively, when compared with control (Table $3)$.

VPA at the 3 doses administered did not significantly affect $(p>0.05)$ ALP and ALT activities in the kidney when compared with control. Similarly, ACP and AST activities in the kidney were not significantly affected $(\mathrm{p}>0.05)$ at 100 and $600 \mathrm{mg} / \mathrm{kg}$ bw but were significantly increased $(\mathrm{p}<0.05)$ at $300 \mathrm{mg} / \mathrm{kg}$ bw when compared with control (Table 4). Furthermore, treatment with VPA at the 3 doses administered did not significantly affect $(p>0.05)$ the serum ALP, ACP, AST and ALT activities (Table 5).

Table 1: Kidney/body weight ratios of rats administered valproic acid (VPA)

\begin{tabular}{ll}
\hline Group & Kidney/body weight ratio \\
\hline Control & $0.0056 \pm 0.0002^{\mathrm{b}}$ \\
$100 \mathrm{mg} / \mathrm{kg}$ bw VPA & $0.0050 \pm 0.0004^{\mathrm{ab}}$ \\
$300 \mathrm{mg} / \mathrm{kg}$ bw VPA & $0.0051 \pm 0.0001^{\mathrm{ab}}$ \\
$600 \mathrm{mg} / \mathrm{kg}$ bw VPA & $0.0052 \pm 0.0003^{\mathrm{ab}}$
\end{tabular}

All data are presented as mean of five replicates \pm standard error of mean (S.E.M.). Values along the same column with different superscripts are significantly different $(\mathrm{p}<0.05)$. 
Table 2: Creatinine and urea concentrations in serum of rats administered valproic acid (VPA)

\begin{tabular}{|c|c|c|c|}
\hline & Group & Creatinine $(\mu \mathrm{mol} / \mathrm{L})$ & Urea $(\mu \mathrm{mol} / \mathrm{L})$ \\
\hline \multirow[t]{4}{*}{ Page | 3690} & Control & $15.5705 \pm 0.909^{\mathrm{a}}$ & $10.426 \pm 2.160^{\mathrm{a}}$ \\
\hline & $100 \mathrm{mg} / \mathrm{kg}$ bw VPA & $43.827 \pm 9.275^{\mathrm{a}}$ & $14.085 \pm 1.509^{\mathrm{ab}}$ \\
\hline & $300 \mathrm{mg} / \mathrm{kg}$ bw VPA & $46.133 \pm 17.592^{\mathrm{a}}$ & $15.096 \pm 1.704^{\mathrm{ab}}$ \\
\hline & $600 \mathrm{mg} / \mathrm{kg}$ bw VPA & $53.053 \pm 15.729^{\mathrm{a}}$ & $14.209 \pm 0.663^{\mathrm{ab}}$ \\
\hline
\end{tabular}

All data are presented as mean of five replicates \pm standard error of mean (S.E.M.). Values along the same column with different superscripts are significantly different $(\mathrm{p}<0.05)$.

Table 3: Concentrations of serum electrolytes in rats administered valproic acid (VPA)

\begin{tabular}{|c|c|c|c|c|}
\hline Group & $\mathrm{K}^{+}(\mathbf{m E q} / \mathbf{L})$ & $\mathrm{Na}^{+}(\mathbf{m E q} / \mathbf{L})$ & $\mathrm{Cl}^{-}(\mathrm{mEq} / \mathrm{L})$ & $\mathrm{PO}_{4}{ }^{2-}(\mathrm{mg} / \mathrm{dL})$ \\
\hline Control & $3.675 \pm 0.621^{\mathrm{a}}$ & $76.704 \pm 12.688^{\mathrm{ab}}$ & $75.943 \pm 8.724^{\mathrm{a}}$ & $15.000 \pm 4.213^{\mathrm{a}}$ \\
\hline $100 \mathrm{mg} / \mathrm{kg}$ bw VPA & $4.372 \pm 0.387^{\mathrm{a}}$ & $53.687 \pm 9.063^{\mathrm{a}}$ & $118.710 \pm 13.142^{a b c}$ & $11.423 \pm 1.537^{\mathrm{a}}$ \\
\hline $300 \mathrm{mg} / \mathrm{kg}$ bw VPA & $4.667 \pm 0.230^{\mathrm{a}}$ & $72.514 \pm 14.284^{\mathrm{ab}}$ & $147.710 \pm 15.668^{c}$ & $20.037 \pm 4.155^{\mathrm{a}}$ \\
\hline $600 \mathrm{mg} / \mathrm{kg}$ bw VPA & $8.558 \pm 0.230^{b}$ & $75.643 \pm 4.015^{\mathrm{ab}}$ & $131.570 \pm 25.266^{\mathrm{bc}}$ & $16.715 \pm 1.488^{a}$ \\
\hline
\end{tabular}

Table 4: Activities of selected enzymes in kidney of rats administered valproic acid (VPA)

\begin{tabular}{|c|c|c|c|c|}
\hline \multirow[t]{2}{*}{ Group } & \multicolumn{2}{|c|}{$\begin{array}{c}\text { Specific Enzyme Activity (nmol/mg } \\
\text { protein/min) }\end{array}$} & \multicolumn{2}{|c|}{ Specific Enzyme Activity (U/mg protein) } \\
\hline & ALP & ACP & AST & ALT \\
\hline Control & $2559.3 \pm 646.911^{\mathrm{a}}$ & $840.15 \pm 149.307^{\mathrm{a}}$ & $1162.30 \pm 555.254^{\mathrm{a}}$ & $617.94 \pm 275.157^{\mathrm{ab}}$ \\
\hline $\begin{array}{l}100 \mathrm{mg} / \mathrm{kg} \mathrm{bw} \\
\mathrm{VPA}\end{array}$ & $941.33 \pm 186.466^{\mathrm{a}}$ & $1252.40 \pm 108.368^{\mathrm{ab}}$ & $1074.20 \pm 123.702^{\mathrm{a}}$ & $235.25 \pm 71.908^{\mathrm{a}}$ \\
\hline $\begin{array}{l}300 \mathrm{mg} / \mathrm{kg} \text { bw } \\
\text { VPA }\end{array}$ & $2060.20 \pm 535.858^{\mathrm{a}}$ & $1857.30 \pm 327.763^{b}$ & $3396.40 \pm 836.901^{b}$ & $304.87 \pm 49.019^{\mathrm{a}}$ \\
\hline $\begin{array}{l}600 \mathrm{mg} / \mathrm{kg} \mathrm{bw} \\
\mathrm{VPA}\end{array}$ & $5888.40 \pm 4315.68^{\mathrm{a}}$ & $961.46 \pm 175.420^{\mathrm{a}}$ & $2260.10 \pm 88.543^{\mathrm{ab}}$ & $783.84 \pm 270.737^{\mathrm{ab}}$ \\
\hline
\end{tabular}

All data are presented as mean of five replicates \pm standard error of mean (S.E.M.). Values along the same column with different superscripts are significantly different $(\mathrm{p}<0.05)$. 
Table 5: Activities of selected enzymes in serum of rats administered valproic acid (VPA)
Group
Specific Enzyme Activity (nmol/mg protein/min)

Page | 3691

\begin{tabular}{|c|c|c|c|c|}
\hline \multirow[t]{2}{*}{ Group } & \multicolumn{2}{|c|}{$\begin{array}{l}\text { Specific Enzyme Activity (nmol/mg } \\
\text { protein/min) }\end{array}$} & \multicolumn{2}{|c|}{ Specific Enzyme Activity (U/mg protein) } \\
\hline & ALP & $\mathbf{A C P}$ & AST & ALT \\
\hline Control & $11.7201 \pm 0.461^{\mathrm{abc}}$ & $4.49 \pm 0.278^{\mathrm{a}}$ & $8.19 \pm 32.434^{\mathrm{a}}$ & $54.75 \pm 10.790^{\mathrm{ab}}$ \\
\hline $\begin{array}{l}100 \mathrm{mg} / \mathrm{kg} \text { bw } \\
\text { VPA }\end{array}$ & $9.6665 \pm 0.819^{\mathrm{abc}}$ & $3.34 \pm 0.105^{\mathrm{a}}$ & $76.26 \pm 29.137^{\mathrm{a}}$ & $50.48 \pm 8.356^{\mathrm{a}}$ \\
\hline $\begin{array}{l}300 \mathrm{mg} / \mathrm{kg} \text { bw } \\
\text { VPA }\end{array}$ & $11.2417 \pm 1.321^{\mathrm{bc}}$ & $4.29 \pm 0.399^{\mathrm{a}}$ & $42.49 \pm 7.022^{\mathrm{a}}$ & $85.34 \pm 8.393^{b}$ \\
\hline $\begin{array}{l}600 \mathrm{mg} / \mathrm{kg} \text { bw } \\
\mathrm{VPA}\end{array}$ & $6.6239 \pm 0.601^{\mathrm{a}}$ & $2.76 \pm 0.226^{\mathrm{a}}$ & $37.72 \pm 21.683^{\mathrm{a}}$ & $65.77 \pm 7.586^{\mathrm{ab}}$ \\
\hline
\end{tabular}

All data are presented as mean of five replicates \pm standard error of mean (S.E.M.). Values along the same column with different superscripts are significantly different $(\mathrm{p}<0.05)$.

\section{Discussion}

This study demonstrated that treatment with valproic acid (VPA) may adversely affect the reabsorption of chloride ion in the kidney at higher doses.

The analysis of organ/body weight ratio is an essential parameter for identifying potentially harmful effects of chemicals in the body. The kidney/body weight ratio is an important index for assessing renal function (Kumar et al., 2005). In this study, administration of VPA did not affect the kidney/body weight ratio in rats (Table 1) suggesting that VPA does not induce renal hypertrophy.

Serum concentrations of urea and creatinine are used to evaluate the functionality of the kidney (Whelton et al., 1994; Oyewole et al., 2012). Higher levels of these biomolecules in the serum, which could be a consequence of reduced glomerular filtration rate, suggest deficiency in renal function (Whelton et al., 1994). Valproic acid, at various doses administered to rats in this study, caused no significant alteration $(p>0.05)$ in serum urea and creatinine concentrations (Table
2) which suggests that the normal functioning of the kidney was not compromised.

Electrolytes play essential roles in many body processes, such as controlling fluid levels, acidbase balance $(\mathrm{pH})$, nerve conduction, blood clotting and muscle contraction (Bhave and Neilson, 2011). Electrolyte levels in the serum are being governed by factors such as diet, renal excretion and pathological conditions and could serve as parameters of kidney function (Guyton and Hall, 2000). Potassium, sodium, chloride and phosphate ions are all important for proper electrolyte balance maintained by the kidney. Derangement of water and electrolyte balance may occur in subjects with consumption of xenobiotics (Kitabchi et al., 2006). Potassium ion is essential in muscle contraction and the transmission of nerve impulses in animals through action potentials and it also influences osmotic balance between cells and the interstitial fluid (Agarwal and Udipi, 2014). Healthy kidneys remove excess potassium ions in the urine to help maintain normal levels in the blood (Terker et al., 2015). The observed significant increase $(\mathrm{p}<$ 0.05 ) in serum potassium ion levels in rats administered $600 \mathrm{mg} / \mathrm{kg}$ body weight of VPA in 
this study could be as a result of its reduced excretion by the kidney or its leakage into the serum from damaged cells and tissues.

Sodium ion plays important roles in maintaining the salt/water balance in the body (Jackson et al., 2014) while phosphate ion, in conjunction with calcium ion help to build and repair bones and teeth and to some extent support muscles and nerves (Jackson et al., 2014). The various doses of VPA administered to rats in this study did not cause any significant alteration $(p>0.05)$ in the serum concentration of sodium and phosphate ions suggesting that VPA protects the body against excessive fluid loss and neuronal dysfunction (Flanigan, 2000). Chloride ion is an important electrolyte located in all body fluids, responsible for maintaining acid/base balance, transmitting nerve impulses and regulating fluid across cell or intracellular membranes (Burtis and Ashwood, 1994). The observed significant increase $(p<0.05)$ in serum level of chloride ion of rats administered 300 and $600 \mathrm{mg} / \mathrm{kg}$ bw of valproic acid could be due to loss of body fluids (dehydration) or a kidney disease. It could also be due to hyper-activity of the parathyroid glands. This can lead to depression of myocardial function and reduce cardiac output, renal and intestinal perfusion (Waters et al., 2001). All these suggest that VPA at higher doses may adversely affect the reabsorption of chloride ion in the kidney which may alter the acid/base balance and impair nerve impulse transmission.

Most enzymes occur in cells at much higher concentrations than in serum. Some occur primarily in cells of certain tissues, where they may be located in different cellular compartments such as the cytoplasm or the mitochondria. 'Normal' serum enzyme levels reflect the balance between the rate of synthesis and release into plasma during cell turnover, and the rate of clearance from the circulation (Sulaiman and Ekanem, 2009). The assessment of the activities of the marker enzymes in tissues and body fluid play a significant and important role in disease diagnosis and in the assessment of drug or plant extract for safety/ toxicity risk (Sulaiman and Ekanem, 2009). Alkaline phosphatase (ALP) is a marker enzyme for plasma membrane integrity (Wright and Plummer, 1974; Akanji et al, 1993), such that any alteration in the activity of the enzyme in tissue, caused by interaction of membrane with xenobiotics (Molina et al, 2005), would indicate likely damages to the plasma membrane of the cells (Yakubu et al., 2006). In this study, VPA did not cause any significant change $(p>0.05)$ in the activity of ALP in both the kidney and serum of rats suggesting that the integrity of the renal membrane is not compromised.

Acid phosphatase (ACP) is a marker enzyme for the lysosome. Different isozymes of ACP are found in different organs and their serum levels are used to diagnose various types of diseases such as prostate cancer (Holtzman, 1989). A significant increase $(\mathrm{p}<0.05)$ in the activity of ACP was observed in the kidney of animals administered $300 \mathrm{mg} / \mathrm{Kg}$ body weight valproic acid but there was no significant change $(p>0.05)$ in its activity in the serum (Tables 4 and 5). This could be as a result of the increased macromolecule digestion and waste removal activities of the lysosomes in the kidney (Holtzman, 1989). Aspartate aminotransferase (AST) and alanine aminotransferase (ALT) are two closely related enzymes involved in amino acid metabolism and well-known biomarkers for predicting possible toxicity to body tissues especially the liver and the kidney (Kechrid and Kenouz, 2003; Sulaiman and Ekanem, 2009). The observed significant increase $(p<0.05)$ in the activity of AST in the kidney of rats administered $300 \mathrm{mg} / \mathrm{kg}$ bw valproic acid but no significant change $(p>0.05)$ in its activity in the serum suggest that the increase in activity was due to an increase in amino acid metabolism in the kidney rather than a damage to the kidney cells. Also, the insignificant effect $(p>0.05)$ of VPA on the 
activity of ALT in both the rat kidney and serum further supports that VPA did not cause renal damage.

\section{Conclusions}

Page | 3693 The findings from this study imply that treatment with VPA at higher doses may adversely affect the reabsorption of chloride ion in the kidney which may alter the acid/base balance and impair nerve impulse transmission.

\section{Conflict of Interest:}

The authors declare no conflicting interest in the publication. No funding was obtained from any funding agency but the research was fully funded by the authors.

\section{References}

Akanji, M. A., Olagoke, O. A. and Oloyede, O. B. (1993). Effect of chronic consumption of metabisulphite on the integrity of the kidney cellular system. Toxicology. 81: $173-179$.

Alam, M. S., Getz, M. and Haldar, K. (2016). Chronic administration of an HDAC inhibitor treats both neurological and systemic Niemann - Pick type C disease in a mouse model. Science Translational Medicine. 8: 326.

Agarwal, A. and Udipi, S. A. (2014). Water, electrolytes and acid-base balance. Textbook of human nutrition. SNDT Women's University, Mumbai, Maharashtra, India. Pp. $1-36$.

Bhave, G. and Neilson, E. G. (2011). Body fluid dynamics: back to the future. Journal of the American Society of Nephrology. 22(12): $2166-2181$.

Biddinger, S. B. and Kahn, C. R. (2006). From mice to men: insights into the insulin resistance syndromes. Annual Review of Physiology. 68: 123 - 158.
Blantz, R.C. (1998). Pathophysiology of pre-renal azotemia. Kidney International. 53 (2): 512 -523 .

Bril, V., England, J., Franklin, G. M., Backonja, M., Cohen, J. Del Toro, D., Feldman, E., Iverson, D. J., Perkins, B., Russell, J. W. and Zochodne, D. (2011). Evidence-based guideline: Treatment of painful diabetic neuropathy: report of the American Academy of Neurology, the American Association of Neuromuscular and Electrodiagnostic Medicine, and the American Academy of Physical Medicine and Rehabilitation. Neurology. 76 (20): 1758 $-1765$.

Burtis, C. A. and Ashwood, E. R. (1994). Tietz textbook of clinical chemistry. 2nd edition, WB Saunders Co., Philedelphia, U.S.A. pp. $1275-1512$.

Chen, H. K., Manji, D. B., Hawver, C. B. and Potter, W. Z. (1994). Chronic sodium valproate selectively decreases protein kinase C alpha and epsilon in vitro. Journal of Neurochemistry. 63 (6): 2361 - 2364.

Edgar, A. D., Tomkiewicz, C. and Costet, P. (1998). Fenofibrate modifies transaminase gene expression via a peroxisome proliferator activated receptor alphadependent pathway. Toxicology Letters. 98: 1323 .

Esiobu, N. and Hoosein, N. (2003). An assessment of the in vitro antimicrobial effects of two antiepileptic drugs-sodium valproate and phenytoin. Antonie van Leeuwenhoek. 83 (1): 63 - 68.

Falkenberg, K. J. and Johnstone, R. W. (2014). Histone deacetylases and their inhibitors in cancer, neurological diseases and immune disorders. Nature Reviews Drug Discovery. 13 (9): $673-691$. 
Flanigan M. J. (2000). Role of sodium in hemodialysis. Kidney International. 58 (76): S72-S78.

Jackson, S. L., Cogswell, M. E., Zhao, L., Terry, Page | 3694 A. L., Wang, C. Y. and Wright, J. (2018). Associations between urinary sodium and potassium excretion and blood pressure among adults in the United States: National Health and Nutrition Examination Survey, 2014. Circulation. 137: 237 - 246.

Igunnu, A., Omotehinse, A., David I., Ogunsola O. S., Oyegoke R. A. (2019). Valproic acid displays anti-diabetic and pro-antioxidant effects in high-fat diet and streptozotocininduced type 2 diabetic rats. Nigerian Journal of Pure \& Applied Science. 32: 3324 -3336 .

Kechrid, Z. and Kenouz, R. (2003). Determination of alkaline phosphatase activity in patients with different zinc metabolic disorders. Turkish Journal of Medical Science. 33: 387 - 391.

Kitabchi, A. E. (2005). Hyperglycemic crises: improving prevention and management. American Family Physician 71: 1659-1660.

Kostrouchova, M., Kostrouch, Z. and Kostrouchova, M. (2007). Valproic acid, a molecular lead to multiple regulatory pathways. Folia Biologica. 53 (2): 37 - 49.

Kumar, A., Abbas Fausto, N. and Robbin, C. (2005). Pathological Basis of Disease, Elsevier Saunders, Philadelphia, Pennsylvania, 7th edition.

Lauterbach, E. C., Victoroff, J., Coburn, K. L. and Shillcutt, S. D. (2010). Psychopharmacological Neuroprotection in Neurodegenerative Disease: Assessing the Preclinical Data. The Journal of Neuropsychiatry and Clinical Neurosciences. 22 (1): $8-18$.
Lee, H. A., Lee, D. Y., Cho, H. M., Kim, S. Y., Iwasaki, Y. and Kim, I. K. (2013). Histone deacetylase inhibition attenuates transcriptional activity of mineralocorticoid receptor through its acetylation and prevents development of hypertension. Circulation Research 112 (7): 1004 - 1012.

Molina, R., Moreno, I., Pichardo, S., Jos, A., Moyano, R., Monterde, J. G. and Cameán, A. (2005). Acid and alkaline phosphatase activities and pathological changes induced in Tilapia fish (Oreochromis sp.) exposed subchronically to microcystins from toxic cyanobacterial blooms under laboratory conditions. Toxicon. 46(7): 725 - 735.

Soori, H., Rabbani-Chadegani, A. and Davoodi, J. (2015). European Journal of Medicinal Chemistry. 89: 844-850.

Sulaiman, F. A. and Ekanem, J. T. (2009). Effect of ibuprofen on the liver function of Trypanosoma infected rats. African Journal of Medical Sciences: 2 (1): 1-4.

Terker, A.S., Zhang, C. and McCormick, J. A. (2015). Potassium modulates electrolyte balance and blood pressure through effects on distal cell voltage and chloride. Cell Metabolism. 21 (1): 39-50.

Verrotti, A., Manco, R. and Agostinelli, S. (2010). The metabolic syndrome in overweight epileptic patients treated with valproic acid. Epilepsia. 51 (2): 268-273.

Waters, J. H., Gottlieb, A., Schoenwald, P., Popovich, M. J., Sprung, J. and Nelson, D. R. (2001). Normal Saline versus Lactated Ringer's Solution for Intraoperative Fluid Management in Patients Undergoing Abdominal Aortic Aneurysm Repair: An Outcome Study. Anesthesia and Analgesia. 93: 817-822. 
Whelton, A., Watson, A. Y. and Rock R. C. (1994). Tietz Textbook of Clinical Chemistry, UK, London: W. B. Saunders Company. pp. $1528-1531$.

Page | 3695 Wright, P. J. and Plummer, D. T. (1974). The use of urinary enzyme measurement to detect renal damages caused by nephrotoxic compounds. Biochemical Pharmacology. 65 (12): 1917 - 2140

Wright, P. J., Leathwood, P. D., and Plummer, D. T. (1972). Enzymes in rat urine: alkaline phosphatase. Enzymologia. 42: 317-327.
Yakubu M. T., Akanji, M. A. and Oladiji, A. T. (2006). Hematological evaluation in male Albino rats following chronic administration of aqueous extract of Fadogia agretis stem. Pharmacognosy Magazine. 3(9): 34-38. 